\section{Stomatal Density in Antirrhinum majus L.: Inheritance and Trends with Development}

\author{
William J. Martin ${ }^{1}$ and Dennis P. Stimart ${ }^{2}$ \\ Department of Horticulture, University of Wisconsin-Madison, 1575 Linden \\ Drive, Madison, WI 53706
}

Additional index words. stomatal index, heritability, indirect selection

Abstract. Stomatal density during plant development and inheritance of the trait were investigated with the goal of utilizing stomatal density as a correlated trait to cutflower postharvest longevity in Antirrhinum majus L. Inbred P1 (stomatal index $=0.2$ ) was hybridized to inbred $\mathrm{P} 2$ (stomatal index $=0.3)$ to produce $\mathrm{F}_{1}(\mathrm{P} 1 \times \mathrm{P} 2)$, which was backcrossed to each parent producing BCP1 $\left(F_{1} \times P 1\right)$ and BCP2 $\left(F_{1} \times P 2\right) . P 1, P 2, F_{1}, B C P 1$, and $\mathrm{BCP} 2$ were used to examine changes in stomatal density with plant development and early generation inheritance. An $F_{2}\left(F_{1}\right.$ self-pollinated), and $F_{3}, F_{4}$, and $F_{5}$ families, derived by self-pollination and single seed descent, were used to obtain information on advanced generation inheritance. Stomatal density was stable over time and with development of leaves at individual nodes after seedlings reached two weeks of age. Therefore, stomatal density can be evaluated after two weeks of plant development from a leaf at any node. Stomatal density is quantitatively inherited with narrow sense heritabilities of $\mathbf{h}^{2}{ }_{\mathrm{F} 2 \cdot \mathrm{F} 3}=$ 0.47 to $0.49, h^{2}{ }_{F 3: F 4}=0.37 \pm 0.06$ to $0.60 \pm 0.07$, and $h^{2}{ }_{F 4: F 5}=0.47 \pm 0.07$ to $0.50 \pm 0.07$. short-lived rose cut flowers remained open longer, implying an inability to respond to water stress (Mayak et al., 1974).

Stomatal densities have little effect upon rates of photosynthesis (Jarvis and Davies, 1998; Jones, 1998) as stomatal density failed to correlate to plant productivity in grass species (Bhagwat and Bhatia, 1993; Wilson, 1971; Yamashita et al., 1995) and in Rhododendron simsii Planch. azalea (Heursel et al., 1987). Stomatal densities have been related to tolerance of environmental stresses, including drought (Jarvis and Davies, 1997; van Rensburg et al., 1999) and temperature extremes (Kleinhenz et al., 1995; Nayeem, 1989), and to water use efficiency in grass species (Bhagwat and Bhatia, 1993; Wilson, 1971; Yamashita et al., 1995). Though plant productivity was deemed difficult to advance, breeding for more efficient water use by modification of stomatal density remained a viable option (Bhagwat and Bhatia, 1993; Wilson, 1971). Moderate to high heritabilities of stomatal density (Bhagwat and Bhatia, 1993; Liang et al., 1975; Miskin et al., 1972; Paul, 1992; Wilson, 1971) suggest breeding for decreased stomatal density can progress
Stoma are important as the primary site of gas exchange and transpirational water loss from plant tissues. Transpirational water loss negatively affects fruit postharvest keeping quality of Musa sp.L., banana and plantain,(Burdon etal., 1991, 1993, 1994; Johnson and Brun, 1966), and Persea americana Mill., avocado, (Blanke and Bower, 1990). However, stoma per area had no effect on cutflower postharvest longevity (PHL) in Zantedeschia sp. Spreng., calla lily (Tjia and Funnell, 1986). In a review of cutflower water relations, transpirational water loss via stoma was cited as a limiting factor in PHL of many species (van Doorn, 1997).

Stomatal function is responsive and sensitive to the environment (van Rensburg et al., 1999). Holding solution additives including hydroxyquinoline compounds (Larsen and Scholes, 1966) and sucrose (Marousky, 1969) increased PHL through stoma closure. Evaluation of cut flowers in the dark increased PHL in A. majus L., snapdragon, (Marousky and Raulston, 1970), and Rosa sp., rose, plant water regulation changed with photoperiod (Slootweg and van Meeteren, 1991) supporting a role for stoma in water balance. Stoma do not function normally in plants grown in vitro (Hartmann et al., 2002) or in greenhouses with high relative humidities (Mortensen and Fjeld, 1998). Nonfunctional stoma result in rose cut flowers with short PHL (Mortensen and Fjeld, 1998; Mortensen and Gislerød, 1999). Under recommended growing conditions, stoma on

Received for publication 14 June 2004. Accepted for publication $31 \mathrm{Aug}$. 2004. A note of gratitude to Erik Nordheim, University of Wisconsin - Madison, for statistical consultation during preparation of this manuscript. Use of trade names does not imply endorsement of the products named or criticism of similar ones not named.

${ }^{1}$ Research associate

${ }^{2}$ Professor and chair of department. To whom reprint requests should be addressed; e-mail dstimart@wisc.edu.
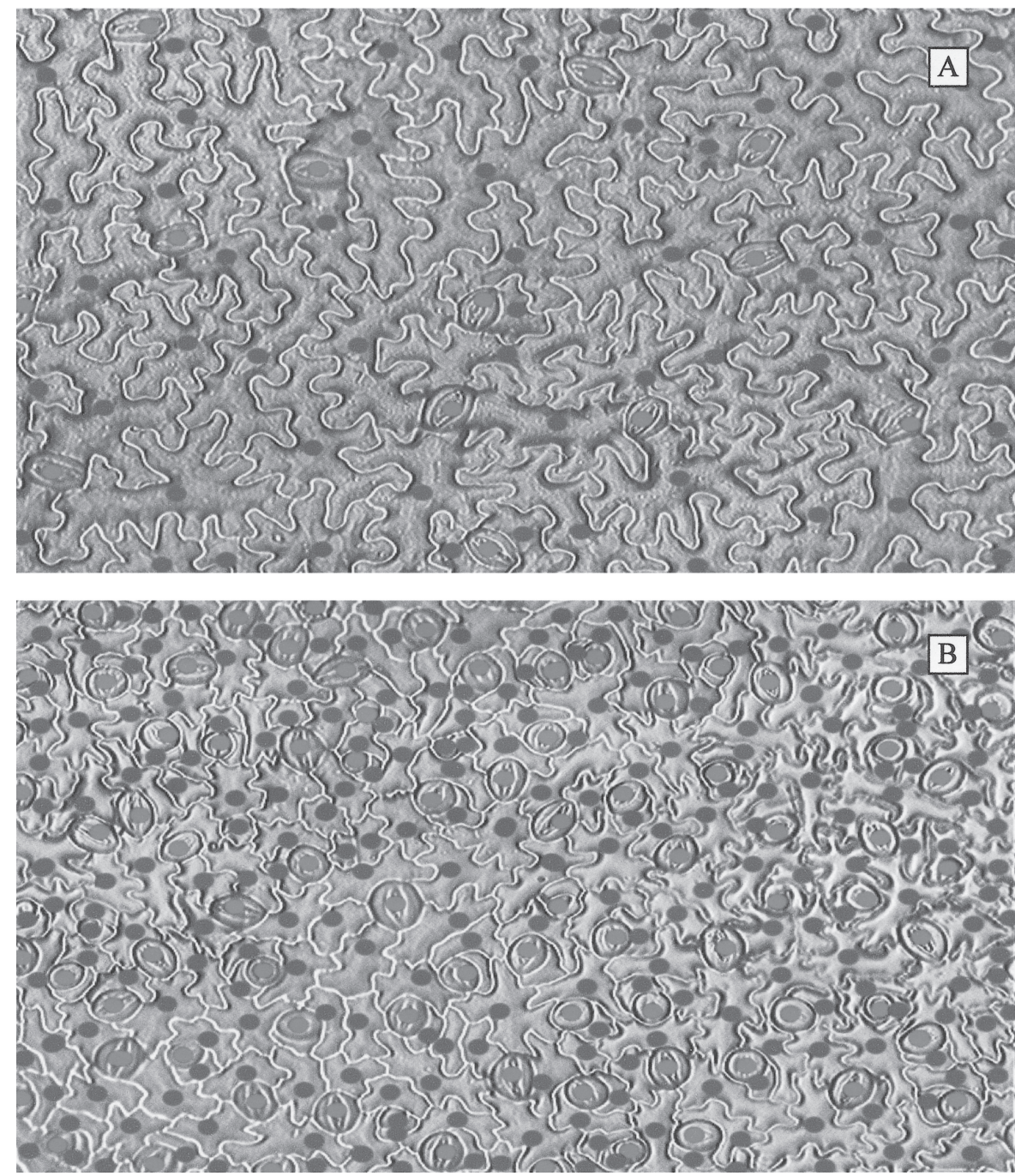

Fig. 1. Low (A) and high (B) extremes of stomatal density in an $\mathrm{F}_{2}$ population derived from a cross of inbreds P1 and P2 in Antirrhinum majus L; stomatal index $=0.15$ and 0.38 , respectively. Red and blue dots locate stoma and epidermal cells, respectively $(130 \times)$. 


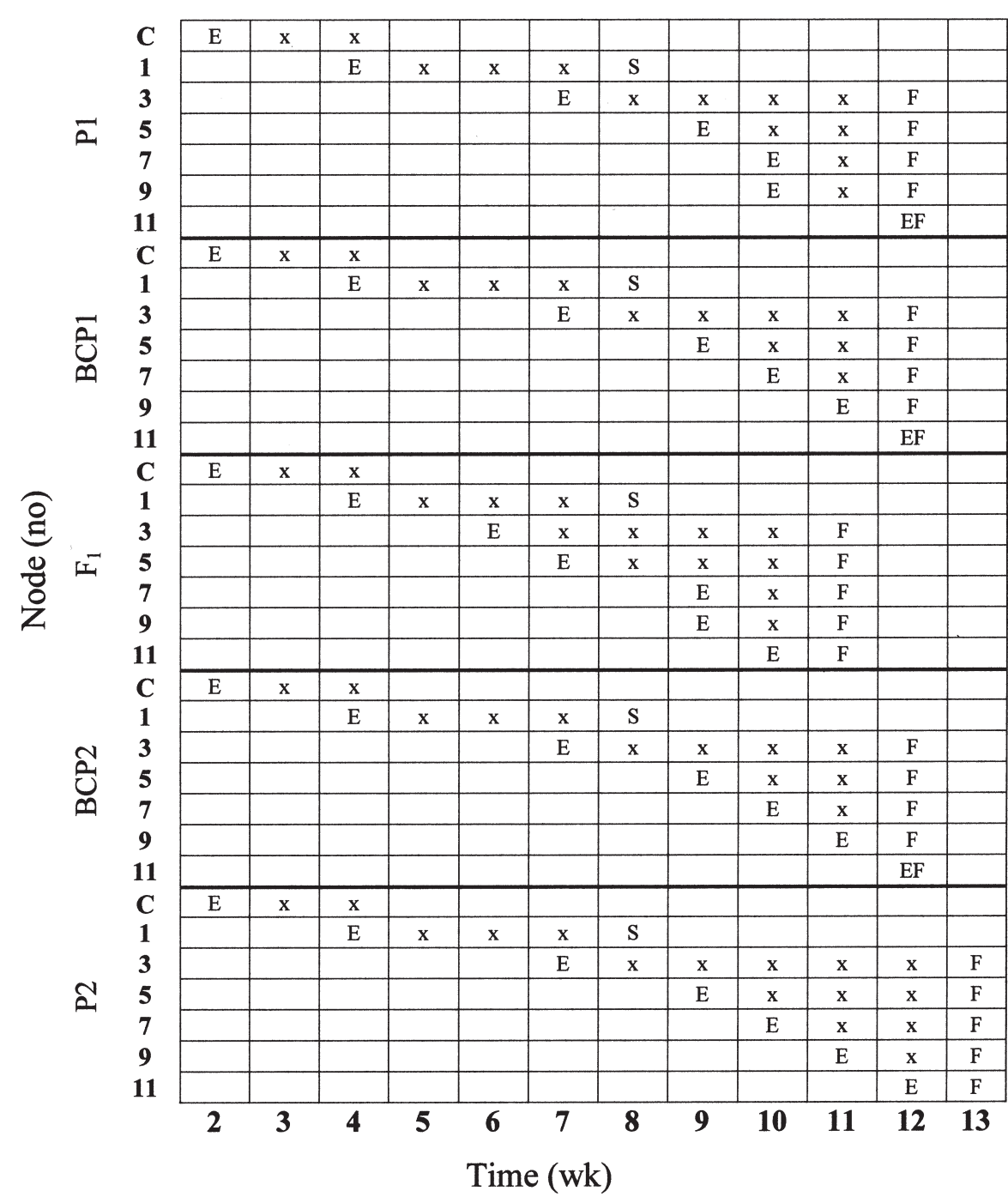

Fig. 2. Sampling scheme of leaf surface images from inbreds $\mathrm{P} 1$ and $\mathrm{P} 2, \mathrm{~F}_{1}(\mathrm{P} 1 \times \mathrm{P} 2)$, and backcrosses $\mathrm{BCP} 1\left(\mathrm{~F}_{1} \times \mathrm{P} 1\right)$ and $\mathrm{BCP} 2\left(\mathrm{~F}_{1} \times \mathrm{P} 2\right)$ of Antirrhinum majus L. Data collected from leaf emergence $(\mathrm{E})$ through leaf senescence $(\mathrm{S})$ or expansion of floral region $(\mathrm{F})$, and on cotyledons $(\mathrm{C})$, the first true leaves at node 1 and from leaves at every second node acropetally at nodes 3 to 11 .

rapidly (Falconer and Mackay, 1996).

Identification and selection of elite germplasm is essential for success of any breeding program. Although selection before anthesis proves beneficial in optimizing resource allocation(Falconer and Mackay, 1996), direct evaluation of PHL before anthesis is not possible. Number of stoma per cutflower, comprised of leaf area and stomatal density, is inversely correlated to PHL in A. majus (Schroeder and Stimart, 1999). Stoma per area and stomatal index are being investigated as potentially correlated traits to PHL that can be evaluated before anthesis and therefore, used in indirect selection for PHL. A caveat to utilization of the relationship between stomatal density and PHL is stomatal density can vary with node position and environmental conditions (Beerling and Chaloner, 1993; Cole and Dobrenz, 1970; Nayeem, 1989; Wild and Wolf, 1980). Leaf stomatal density is examined to verify proper evaluation of this environmentally sensitive trait and to provide inheritance information in early and advanced generations of $A$. majus with relevance to future work on PHL.

\section{Methods and Materials}

Commercial inbred lines of $A$. majus were evaluated for cutflower postharvest longevity (PHL) in 1991 and 1992 at the University of Wisconsin-Madison (Stieve and Stimart, 1994). The two inbred lines selected represented extremes in PHL, P1 (white, $16.3 \mathrm{dPHL}$ ) and P2 (white, $3.0 \mathrm{~d}$ PHL) (Stieve and Stimart, 1994). Also, P1 and P2 vary for stomatal index, 0.2 and 0.3 , respectively (Schroeder and Stimart, 1999). P1 and P2 were self-pollinated for five generations and hybridized to produce an $\mathrm{F}_{1}(\mathrm{P} 1 \times \mathrm{P} 2)$ that was backcrossed to each parent to form BCP1 $(\mathrm{F}, \times \mathrm{P} 1)$ and $\mathrm{BCP} 2(\mathrm{~F}$ $\times$ P2) lines. Hereafter, P1, P2, $F_{1}, B C P 1$, and $\mathrm{BCP} 2$ are termed foundation genotypes.

$\mathrm{F}_{1}(\mathrm{P} 1 \times \mathrm{P} 2)$ were self-pollinated to produce $\mathrm{F}_{2}$ populations. From the $\mathrm{F}_{2}, 485$ plants were selected randomly and self-pollinated to produce $\mathrm{F}_{3}$ families. A total of 155 randomly selected $\mathrm{F}_{3}$ families were advanced through single-seed descent to the $\mathrm{F}_{5}$. Seed set and germination failures resulted in loss of 19 families, $12 \%$ of the population, by the $\mathrm{F}_{4}$; and 4 families, $3 \%$ of the population, by the $\mathrm{F}_{5}$. Thus, $132 \mathrm{~F}_{3}, \mathrm{~F}_{4}$ and $F_{5}$ families remained with 110 randomly selected for evaluation. Poor germination in the 110 families being evaluated resulted in $4 \%$ reduction of the population. In addition, 620 plants were selected randomly from the $\mathrm{F}_{2}$ and self-pollinated to produce $\mathrm{F}_{3}$ families; $101 \mathrm{~F}_{3}$ were selected randomly for evaluation.

Foundation genotypes were grown in Winter 1998-99 in a completely random design for stomatal evaluations (described below). The $620 \mathrm{~F}_{2}$ were grown in Fall 1999 and the derived $\mathrm{F}_{3}$ in Spring 2000 for stomatal evaluations. Individuals from each of $\mathrm{P} 1, \mathrm{P} 2, \mathrm{~F}_{1}$, $\mathrm{F}_{3}, \mathrm{~F}_{4}$, and $\mathrm{F}_{5}$ were grown in Winter 2001-02 in a randomized complete block design (three blocks, one replication per genotype/block) for stomatal evaluations. All plants were grown in a polyhouse at the University of Wisconsin-Madison according to standard forcing procedures (Rogers, 1992). Briefly, seeds were germinated in a cell of a cell pack and seedlings individually transplanted to 96-cell $\left(65-\mathrm{cm}^{3}\right)$ flats. Seedlings were transplanted to square plastic pots $\left(1250 \mathrm{~cm}^{3}\right)$ when the third to fourth set of true leaves appeared and grown through anthesis. Growing medium consisted of equal volumes soil, peat and perlite. Plant bench spacing was on $22-\mathrm{cm}$ centers. Plants were fertilized every other week with 200 $\mathrm{mg} \cdot \mathrm{L}^{-1} \mathrm{~N}$ using Peter's 20N-8.7P-16.6K (Scott's Sierra Horticultural Products Co., Marysville, Ohio) and provided supplemental light of $27 \mu \mathrm{mol} \cdot \mathrm{m}^{-2} \cdot \mathrm{s}^{-1}$ at bench level using 1,000-W high-pressure sodium lamps from 0600 through $2400 \mathrm{HR}$.

Stoma per area and stomatal index, $\{[$ (number of stoma/number of stoma + number of epidermal cells) per area] $\cdot 100\}$ (Salisbury, 1927 as referenced by Lea et al., 1977), were assessed using abaxial leaf imprints created in super glue on glass microscope slides (Sampson, 1961). Fully expanded leaves from the third node above soil line were sampled destructively 8 weeks after seed sowing. Leaf samples were taken from ten plants per foundation genotype, single plants of $620 \mathrm{~F}$, and three plants per $\mathrm{F}_{3}, \mathrm{~F}_{4}$ and $\mathrm{F}_{5}$ families. Three; two; and one image(s), $0.24 \mu^{2}$, per leaf imprint were collected for foundation genotypes; $\mathrm{F}_{2}$; and $\mathrm{F}_{3}, \mathrm{~F}_{4}$, and $\mathrm{F}_{5}$ families, respectively. Digital images were collected from the distal one third of each leaf using iMovie (Apple Computer, Inc., Cupertino, Calif.) and analyzed using Adobe Photoshop 5.5 (Adobe Systems Inc., San Jose, Calif.) (Fig. 1).

Changes in stomatal index over foundation genotype development were examined. Abaxial leaf imprints, described above, were collected weekly from cotyledons, first true leaves, and from leaves on every second node acropetally (sampling scheme Fig. 2). Data collection on cotyledons was terminated when cotyledons were placed below soil level at final transplant. Termination of data collection at other nodes occurred with leaf senescence or floral region expansion. Leaves were sampled destructively from five plants out of a group of 30 plants of each foundation genotype. Images were collected and analyzed as described above. Due to differing times until anthesis in 


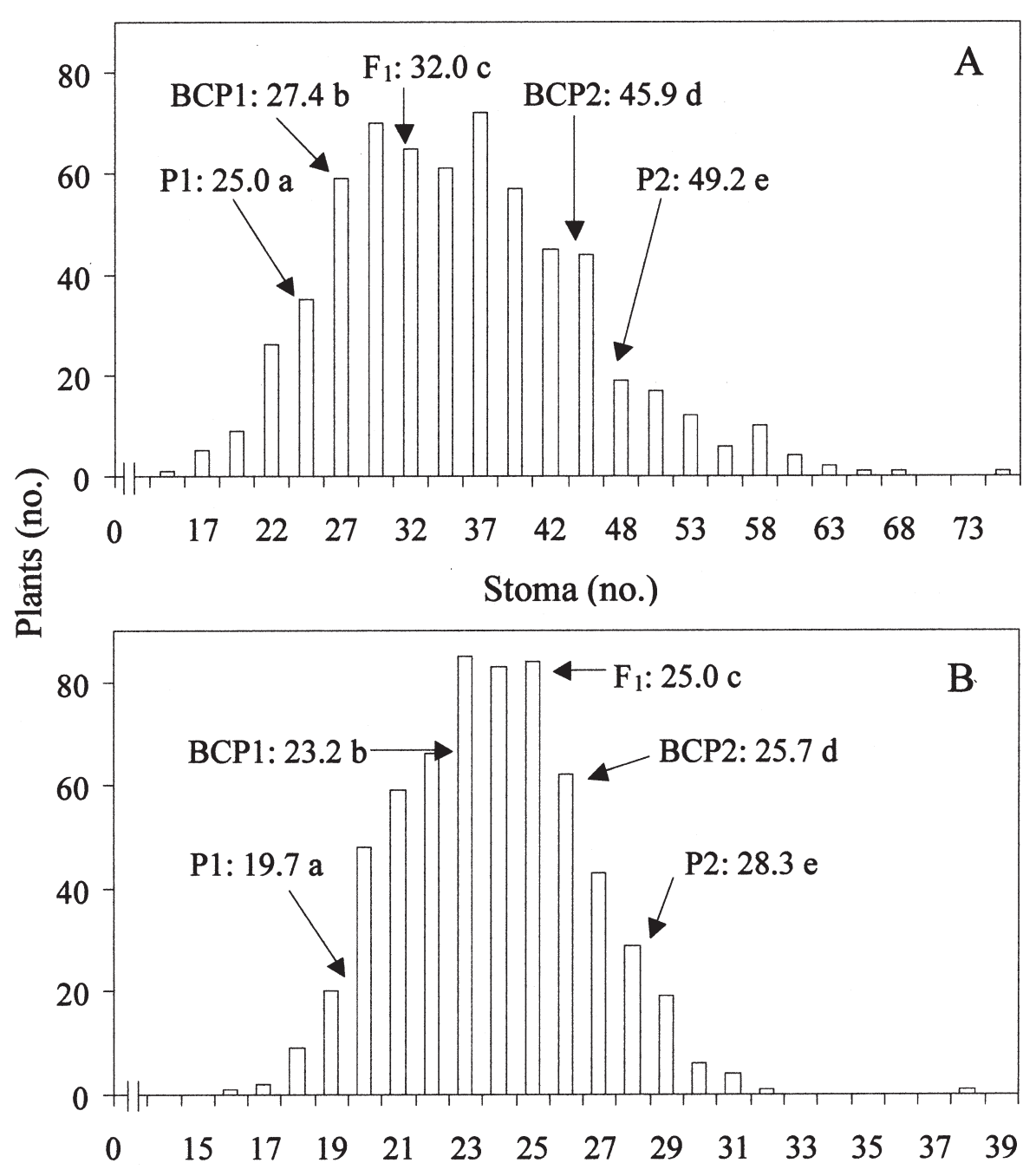

\section{Stomatal index}

Fig. 3. Stomatal densities (A) and indices (B) in an $\mathrm{F}_{2}$ population derived from a cross of inbreds $\mathrm{P} 1$ and $\mathrm{P} 2$ in Antirrhinum majus $\mathrm{L} ., \mathrm{n}=620 . \mathrm{P} 1, \mathrm{P} 2, \mathrm{~F}_{1}(\mathrm{P} 1 \times \mathrm{P} 2)$, and backcross $\mathrm{BCP} 1\left(\mathrm{~F}_{1} \times \mathrm{P} 1\right)$ and $\mathrm{BCP} 2$ $\left(\mathrm{F}_{1} \times \mathrm{P} 2\right)$ mean values located by arrows. Letters represent mean separation of $\mathrm{P} 1, \mathrm{P} 2, \mathrm{~F}_{1}, \mathrm{BCP} 1$, and $\mathrm{BCP} 2$ by $\mathrm{LSD}_{0.05}(\mathbf{A})=1.6$ stoma and $(\mathbf{B})=0.6$.

foundation genotypes (Fig. 2) and for stomatal index comparisons across development, data collection times were equalized on a 0 to 1 scale within a genotype relative to time until floral

region expansion and termed equalized time. Data for each node and position in equalized time were averaged for analysis across weeks and nodes, respectively.

Table 1. Observed and expected, simple-inheritance segregation of stomatal index and stoma per area in inbreds P1 and P2, $\mathrm{F}_{1}(\mathrm{P} 1 \times \mathrm{P} 2)$, and backcrosses BCP1 $\left(\mathrm{F}_{1} \times \mathrm{P} 1\right)$ and BCP2 $\left(\mathrm{F}_{1} \times \mathrm{P} 2\right)$ of Antirrhinum majus L.

\begin{tabular}{|c|c|c|c|c|c|}
\hline Genotype & $\begin{array}{c}\text { Observed } \\
\text { stomatal index }\end{array}$ & $\sigma^{2}$ & $\begin{array}{c}\text { Expected } \\
\text { stomatal index }\end{array}$ & $t$ value $^{\mathrm{y}}$ & Significance \\
\hline \multicolumn{6}{|c|}{ Stomatal index } \\
\hline P1 & 19.7 & 4.61 & & & \\
\hline BCP1 & 23.2 & 9.11 & 22.4 & 1.66 & NS \\
\hline $\mathrm{F}_{1}$ & 25.0 & 5.92 & 24.0 & 2.10 & NS \\
\hline BCP2 & 25.7 & 5.26 & 26.7 & -2.22 & NS \\
\hline $\mathrm{P} 2$ & 28.3 & 9.42 & & & \\
\hline \multicolumn{6}{|c|}{ Stoma per area $t$ value ${ }^{y}$} \\
\hline P1 & 25.0 & 23.69 & & & \\
\hline BCP1 & 27.4 & 36.32 & 28.5 & -1.07 & NS \\
\hline $\mathrm{F}_{1}$ & 32.0 & 25.59 & 37.3 & -3.10 & $*$ \\
\hline BCP2 & 46.6 & 153.51 & 40.8 & 4.71 & $*$ \\
\hline $\mathrm{P} 2$ & 49.6 & 77.28 & & & \\
\hline
\end{tabular}

${ }^{\mathrm{z}} \mathrm{F}_{1}=$ midparent value, $\mathrm{BCP} 1$ and $\mathrm{BCP} 2=$ (midparent value - respective inbred parent value $)$.

y Derived by pairwise $t$ test.

*Significant $t$ value at $p \leq 0.05$.
Statistical analysis was completed via ANOVA using generalized linear and mixed models in the SAS statistical package (Littell et al., 1996) where appropriate. $\mathrm{R}^{2}$ values from regression were compared with established tables for significance (Steel and Torrie, 1980). Foundation genotype stoma per area and stomatal index means were separated by LSD (Littell et al., 1996; Steel and Torrie, 1980). Stoma per area and stomatal index are assumed to follow simple Mendelian inheritance and expected midparent and backcross mean values were calculated as defined in Poehlman and Sleper (1995). Narrow sense heritability and standard error estimates were calculated via parent-offspring regression (Falconer and Mackay, 1996).

\section{Results and Discussion}

Stoma per area and stomatal index in the $\mathrm{F}_{2}$ show normal distributions (Fig. 3). $\mathrm{F}_{1}$ falls intermediate to $\mathrm{P} 1$ and $\mathrm{P} 2$, and $\mathrm{BCP} 1$ and $\mathrm{BCP} 2$ fall intermediate to $\mathrm{F}_{1}$ and respective parents. All foundation genotype means are significantly different. $F_{1}$ stoma per area is intermediate to $\mathrm{P} 1$ and $\mathrm{P} 2$ with a significant bias towards $\mathrm{P} 1$ from the expected midparent value (Fig. 3a, Table 1). Incomplete dominance for stomatal density in the $\mathrm{F}_{1}$ toward low parent has been reported in corn (Zea mays L.) (Heichel, 1971) and toward high parent in tobacco (Nicotiana tabacum L.) (Tell, 1985). Significant specific combining ability, hence significant dominance variance, was reported in forage rape (Brassicanapus L.) (Paul, 1992) though dominance direction was not reported, and mating-specific directional dominance was shown in sorghum (Sorghum bicolor Moench.) (Liang et al., 1975) and mango (Mangifera indica L.) (Arora et al., 1978). $\mathrm{F}_{1}$ stoma per area relative to $\mathrm{P} 1$ and $\mathrm{P} 2$ suggests inheritance is partially dominant in A. majus. However, failure of BCP 1 and $\mathrm{BCP} 2$ to follow expected segregation patterns suggests stoma per area may be more complexly inherited or may reveal expected environmental sensitivity of the trait.

Stoma per area is reported commonly in the literature; however, this value has the detriment of being environmentally sensitive whereas stomatal index is a more robust measure of stomatal density (Salisbury, 1927 as referenced by Lea et al., 1977). The environment affects the number of guard cell initials early in leaf development, which thereby affects stomatal index (Beerling and Chaloner, 1993; Pappas et al., 1988). Therefore, stomatal index should be unaffected by environmental conditions that affect growth (Walton, 1980), whereas stoma per area may. Environmental conditions known to affect stomatal density include light quality (Miskin and Rasmusson, 1970; Rawson and Craven, 1975; Wild and Wolf, 1980), moisture (Nayeem, 1989), and carbon dioxide concentration and temperature (Beerling and Chaloner, 1993). Growing foundation genotypes simultaneously for evaluation should standardize environmental impact upon stomatal density.

The $F_{1}$ stomatal index value is not significantly different from expected midparent value 

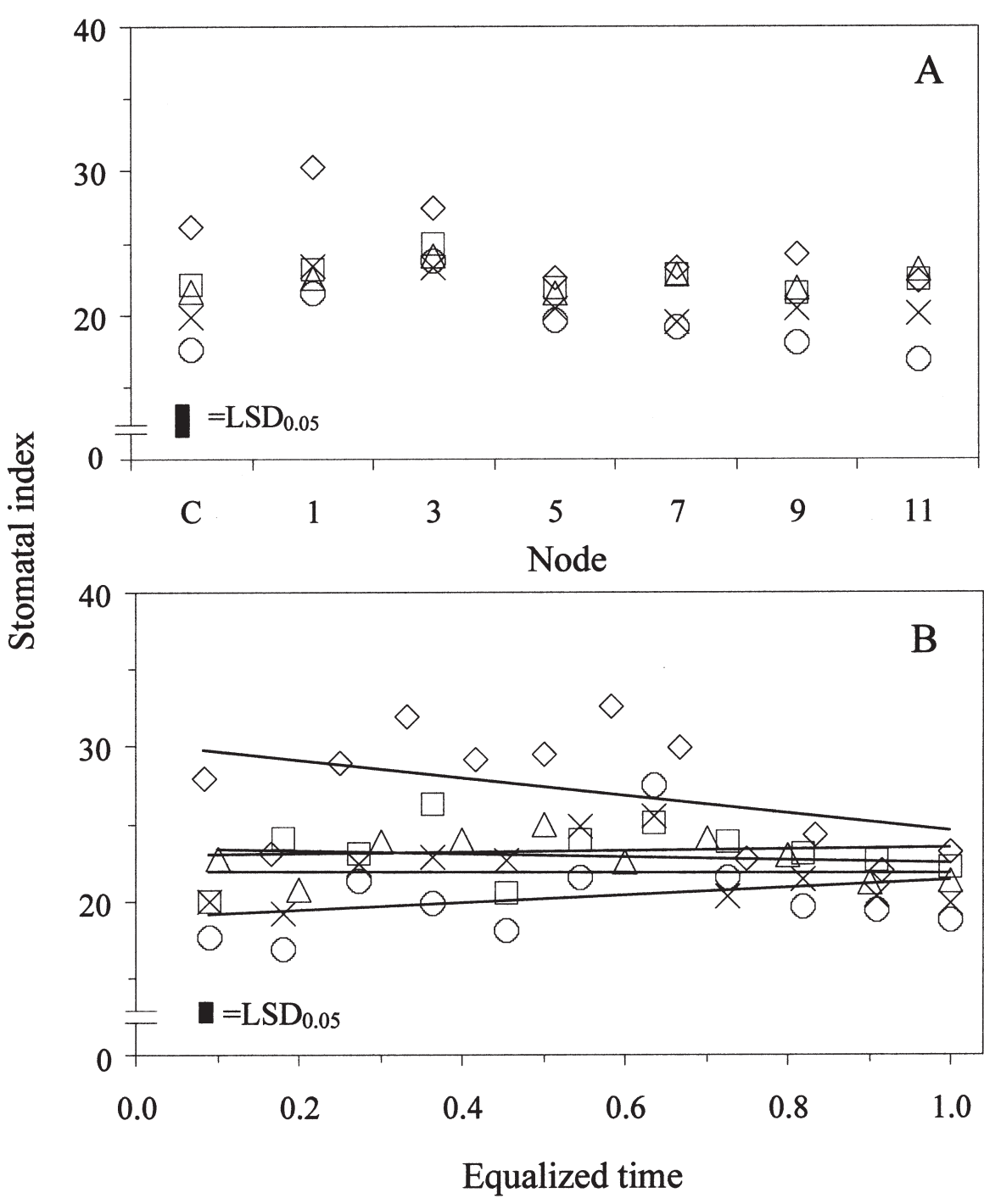

Fig. 4. Stomatal index over node (A) and equalized time (B) in Antirrhinum majus L. inbreds P1 ( $\square$ ) and P2 $(\diamond), \mathrm{F}_{1}(\mathrm{P} 1 \times \mathrm{P} 2, \Delta)$, and backcrosses BCP1 $\left(\mathrm{F}_{1} \times \mathrm{P} 1, \times\right)$ and BCP2 $\left(\mathrm{F}_{1} \times \mathrm{P} 2, \square\right) . \mathrm{C}=$ cotyledons. $\operatorname{LSD}_{005}(\mathbf{A})=1.7$ and $(\mathbf{B})=1.2$.

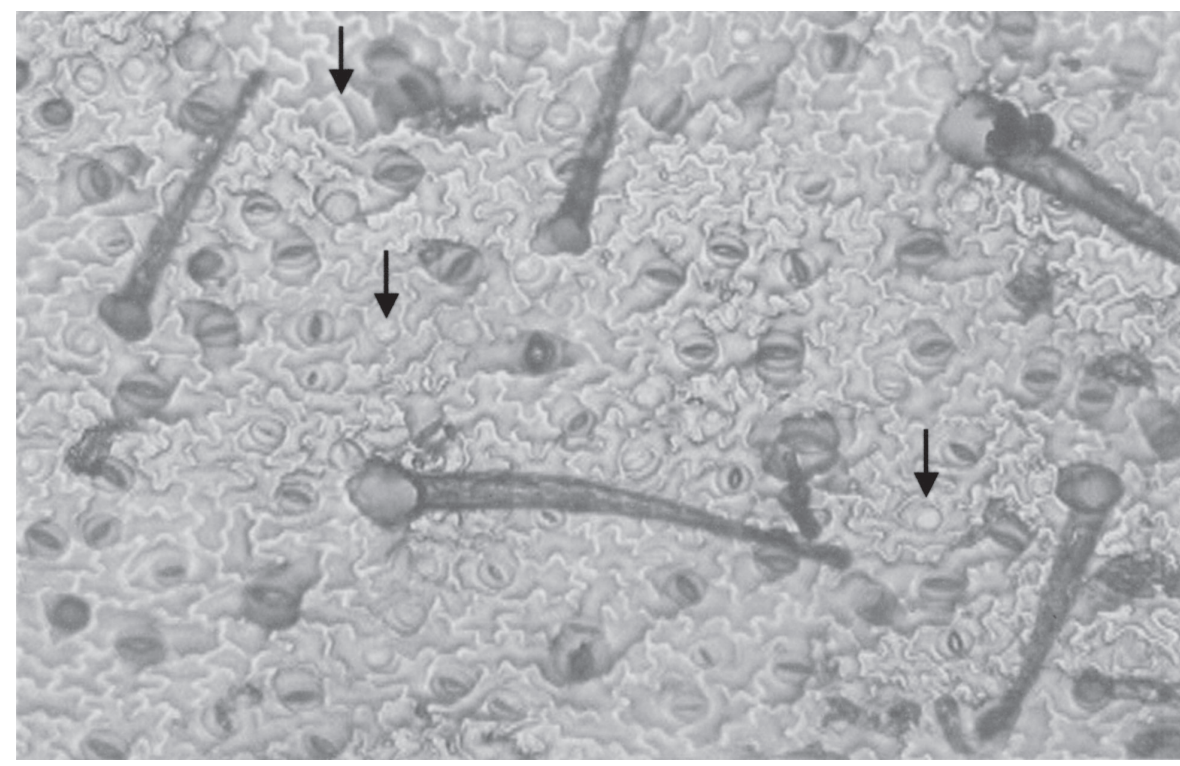

Fig. 5. Nonsynchronized stomatal development on a cotyledon of Antirrhinum majus L. Arrows designate comparatively juvenile stoma $(130 \times)$.
(Fig. 3b). Stomatal index in A. majus appears to be inherited simply, as $\mathrm{F}$, falls intermediate to $\mathrm{P} 1$ and $\mathrm{P} 2$ and backcross populations fall intermediate between $F_{1}$ and respective parents (Poehlman and Sleper, 1995). Inheritance of stomatal index was reported as partially dominant in Solanum sp., potato, though backcrosses did not follow expected segregation (Kleinhenz et al., 1995). Lack of agreement between inheritance of stoma per area and stomatal index can be explained by sensitivity of stoma per area estimates to varying growth rates. As shown above (Fig. 2), foundation genotypes reach anthesis at different times after seed sowing; therefore during sampling, plants are at different developmental stages. Stoma per area may be sensitive to this variation between genotypes, whereas stomatal index is robust against variation generated by growth rates. Inheritance of stomatal density is quantitative and stomatal index is best for genotype comparisons due to reduced environmental sensitivity.

Transgressive segregation in the $\mathrm{F}_{2}$ is observed for stoma per area and stomatal index (Fig. 3). Since P1 and P2 were selected as extremes for PHL and vary for stoma per area, transgressive segregation can be expected and suggests presence of genetic variation for the trait (Falconer and Mackay, 1996). Similarly, high parent (Arora et al., 1978; Heichel, 1971) and bidirectional (Bhagwat and Bhatia, 1993) transgressive segregation of stoma per area have been reported when parents were selected to differ for the trait. Stomatal density has limited impacts on net carbon dioxide assimilation, but affects water use efficiency (Jones, 1998; Wild and Wolf, 1980). Therefore, transgressive segregation in stoma per area or stomatal index may best be utilized in a program to breed for reduction in transpiration rates as proposed in wheat (Triticum aestivum L.) (Bhagwat and Bhatia, 1993).

Stomatal index for $\mathrm{F}_{1}, \mathrm{BCP} 1$, and BCP2 is low in cotyledons, shows an increase through the third set of true leaves, falls slightly at the fifth node, and then is stable acropetally (Fig. 4A). P1 and P2 vary slightly from this pattern. $\mathrm{P} 1$ stomatal index varies with a decrease at node 11 and P2 stomatal index starts high, shows an increase in the first set of true leaves and then follows a pattern similar to other genotypes (Fig. 4A). Stomatal density decreases from the plant apex in alfalfa (Medicago sativa L.) (Cole and Dobrenz, 1970), Triticum sp. (Nayeem, 1989), and Z. mays (Heichel, 1971), to peak at midplant in soybean (Glycine max L.) (Lugg and Sinclair, 1979), and be uniform across leaf position in sunflower (Helianthus annum L.) and N. tabacum (Rawson and Craven, 1975). In addition, variability in stomatal density with leaf position is cautioned against for sampling purposes in Brassica napus L. (Paul, 1992), bromegrass (Bromus inermis Leyss) (Walton, 1980), and rice (Oryza sativa L.) (Yamashita et al., 1995). An extensive study in A. majus (Harte and Hansen, 1971) using nine cultivars reported stomatal index stability in evaluated whorls in seven cultivars and an increase and decrease in the remaining two, respectively. Stability of stomatal index with leaf position 


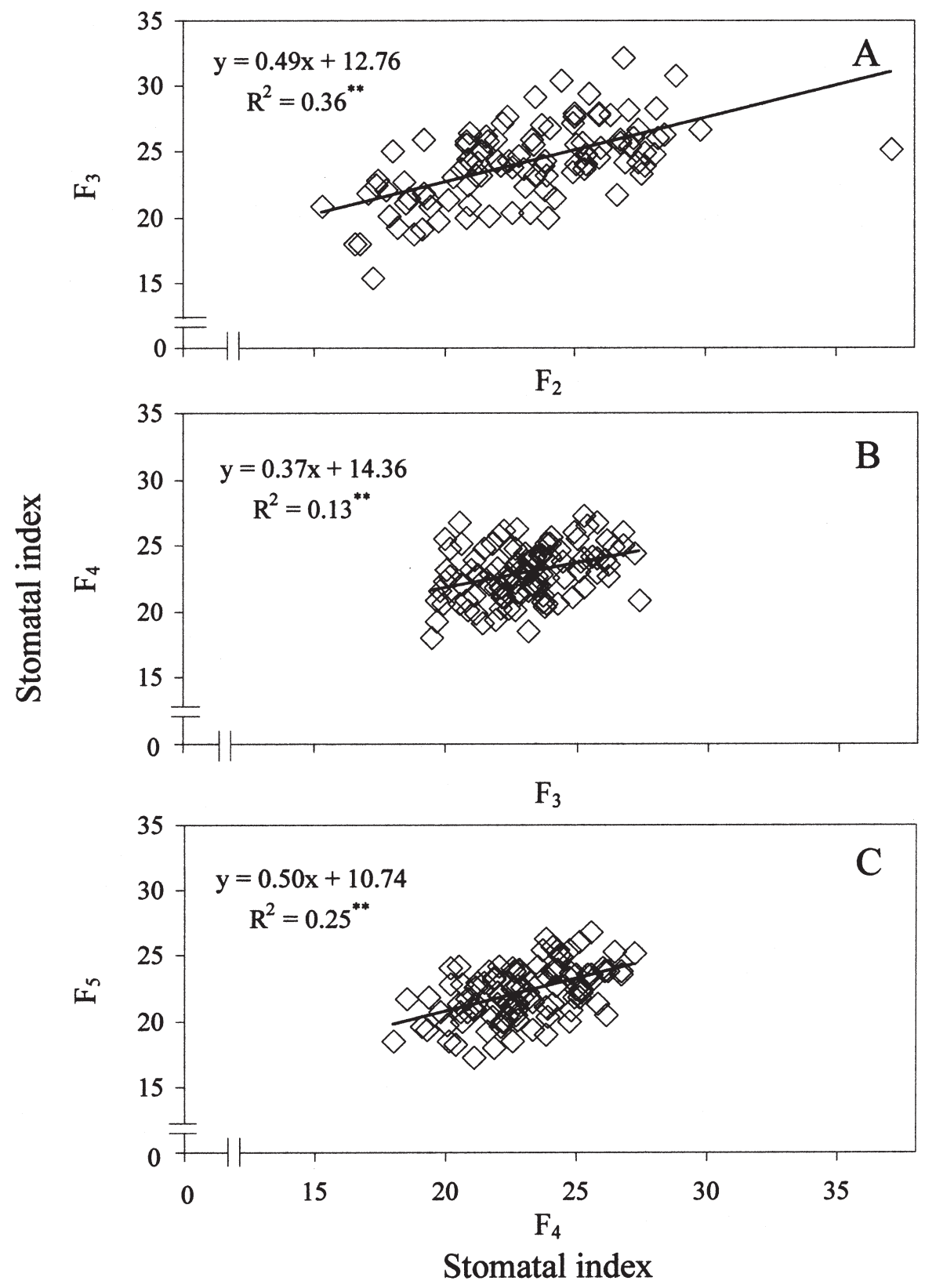

Fig. 6. Regression of $\mathrm{F}_{3}$ on $\mathrm{F}_{2}(\mathbf{A}), \mathrm{F}_{4}$ on $\mathrm{F}_{3}(\mathbf{B})$, and $\mathrm{F}_{5}$ on $\mathrm{F}_{4}(\mathbf{C})$ stomatal index in Antirrhinum majus $\mathrm{L}$. $\mathrm{n}=101(\mathbf{A})$ and $105(\mathbf{B}$ and $\mathbf{C}) .{ }^{* *}$ Significant at $P \leq 0.01$.

reported here agrees with previous work in A. majus.

Stomatal index over equalized time of development is stable for all genotypes (Fig. 4B). Stomatal ontogeny is set early in leaf development and spreading of stoma due to growth of epidermal cells occurs with leaf expansion (Pappas et al., 1988). Therefore, stomatal ontogeny has been described as synchronous (Pappas et al., 1988); however in some dicotyledons, additional stoma may be added during leaf expansion though their relative number is low (Larkin et al., 1997). In both scenarios, stoma at various stages of development may be seen side by side (Pappas et al., 1988; Zhao and Sack, 1999) with distinguishable stoma proximal to cells that later develop into stoma. This variable rate of stomatal development is observed in A. majus (Fig. 5) though stomatal ontogeny is not known. regressions show greater distributions than others, especially for stomatal index, due to $F_{2}$ estimates being an average of measurements from only one plant. Agreement between $\mathrm{h}^{2}$ for the two traits is expected in that both represent measures of stomatal density and are presented for literature comparisons. Published $\mathrm{h}^{2}$ estimates for stomatal density include 0.82 to 0.85 in B. napus L. (Paul, 1992), $0.27 \pm 0.06$ to $0.74 \pm 0.15$ in barley (Hordeum vulgare $\mathrm{L}$.) (Miskin et al., 1972), $0.52 \pm 0.06$ in grassland ruanui (Lolium perenne L.) (Wilson, 1971), $1.02 \pm 0.24$ in S. bicolor (Liang et al., 1975), $\mathrm{h}_{\mathrm{F} 3 \mathrm{~F} 4}^{2}=0.42$ and $\mathrm{h}_{\mathrm{F} 4: \mathrm{F} 5}^{2}=0.81$ in $T$. aestivum (Bhagwat and Bhatia, 1993), and broad sense heritability of 0.85 in B. inermis (Walton, 1980), and 0.95 to 0.96 in cowpea (Vigna unguiculata Walp.) (Hazra et al., 1996). In addition, using parents that deviated for stomatal frequency, simple quantitative inheritance was demonstrated in N. tabacum (Tell, 1985) and Z. mays (Heichel, 1971).

Heritability estimates can be affected by environment, experimental design, species, population, sampling techniques, and complex interactions of these factors (Falconer and Mackay, 1996). High $\mathrm{h}^{2}$ for stomatal frequency in several species suggests adequate control of these factors, although standard error estimates are not always presented. Heritability estimates for stomatal index are likely, due to nonindependent data, to be very similar to published results for stoma per area within a given study. In addition, comparison of stomatal index $\mathrm{h}^{2}$ to published results for stoma per area $h^{2}$ is supported by mathematical nonindependence of data and agreement between $\mathrm{h}^{2}$ estimates for the two traits in A. majus. Estimates of moderate $\mathrm{h}^{2}$ for stomatal index and stoma per area in A. majus agree with published results for other species, though increased sampling in A. majus may improve $\mathrm{h}^{2}$.

The nature of stomatal density was investigated due to previous knowledge of the inverse relationship between total stoma per cutflower and PHL in A. majus. Stomatal index was stable over leaf position though standardized sampling is advised. Stomatal index, being an environmentally robust measure of stomatal density, is a quantitative trait with simple inheritance in A. majus. The bidirectional transgressive segregation and moderate narrow sense heritability estimates for stoma per area and stomatal index suggest selection for these traits is feasible. With this knowledge in hand, the physiological influence of stomatal density on PHL can be elucidated through further work.

\section{Literature Cited}

Arora, I.K., P.K. Majumder, and R.M. Singh. 1978. Inheritance of rootstock characters pertaining to vigour in mango (Mangifera indica L.). Sci. Cult. 44:425-426.

Beerling, D.J. and W.G. Chaloner. 1993. The impact of atmospheric $\mathrm{CO}_{2}$ and temperature change on stomatal density: Observations from Ouercus robur Lammas leaves. Ann. Bot. 71:231-235.

Bhagwat, S.G. and C.R. Bhatia. 1993. Selection for flag leaf stomatal frequency in bread wheat. Plant Breeding 110:126-136.

Blanke, M.M and J.P. Bower. 1990. Possible role of 

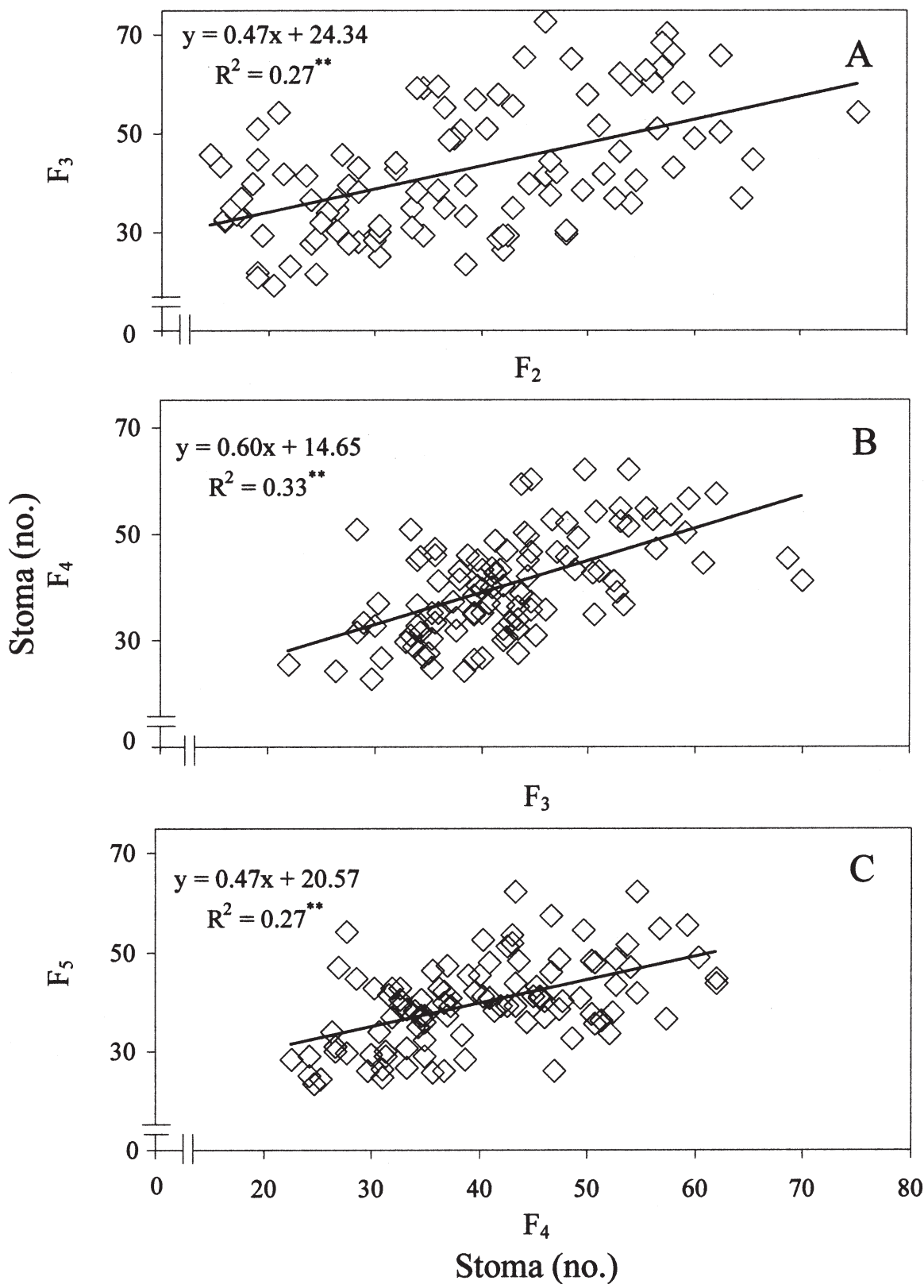

Fig. 7. Regression of $\mathrm{F}_{3}$ on $\mathrm{F}_{2}(\mathbf{A}), \mathrm{F}_{4}$ on $\mathrm{F}_{3}(\mathbf{B})$ and $\mathrm{F}_{5}$ on $\mathrm{F}_{4}(\mathbf{C})$ stoma number in Antirrhinum majus L. $\mathrm{n}$ $=101(\mathbf{A})$ and $105(\mathbf{B}$ and $\mathbf{C}) .{ }^{* *}$ Significant at $P \leq 0.01$

stomata in transpiration of avocado fruit. Acta Hort. 275:449-450

Burdon, J.N., K.G. Moore, and H. Wainwright 1991. The post-harvest ripening of three plantain cultivars (Musa spp., AAB group). Fruits 46:137-143.

Burdon, J.N., K.G. Moore, and H. Wainwright. 1993. Postharvest water loss of plantain and cooking banana fruits. Acta Hort. 343:307-308.

Burdon, J.N., K.G. Moore, and H. Wainwright. 1994. An examination of the stomata of the fruits of plantains (Musa spp., AAB group) and cooking bananas (Musa spp., ABB groups). J. Hort. Sci. 69:81-88

Cole, D.F. and A.K. Dobrenz. 1970. Stomate density of alfalfa (Medicago sativa L.). Crop Sci. 10:61-63.

Falconer, D.S. and T.F.C. Mackay. 1996. Introduction to quantitative genetics. 4th ed. Addison Wesley Longman Ltd., Edinburgh Gate, Harlow Essex, U.K.
Harte, V.C. and H. Hansen. 1971. Das spaltoffnungsmuster in der blattepidermis einer standardsippe und einiger mutanten von Antirrhinum majus L. Biologisches Zentralblatt 90:1-26.

Hartmann, H.T., D.E. Kester, F.T. Davies, Jr., and R.L. Geneve. 2002. Plant propagation, principles and practices, p. 650-651.7th ed. Prentice Hall, Upper Saddle River, N.J.

Hazra, P., P.K. Das and M.G. Som. 1996. Variability in stomatal frequency, length and breadth in cowpea (Vigna unguiculata (L.) Walp.). Crop Res. 11:78-83.

Heichel, G.H. 1971. Genetic control of epidermal cell and stomatal frequency in maize. Crop Sci. 11:830-832.

Heursel, J., R. Ceulemans, and N. Ibrahim. 1987. Stomatal density and length for breeding of Evergreen Azaleas (Rhododendron simsii Planch.). Plant Breeding 99:340-343.

Jarvis, A.J. and W.J. Davies. 1997. Whole-plantABA flux and the regulation of water loss in Cedrella odorata. Plant Cell Environ. 20:521-527.

Jarvis, A.J. and W.J. Davies. 1998. The coupled response of stomatal conductance to photosynthesis and transpiration. J. Expt. Bot. 49:399-406.

Johnson, B.E. and W.A. Brun. 1966. Stomatal density and responsiveness of banana fruit stomates. Plant Physiol. 41:99-101.

Jones, H.G. 1998. Stomatal control of photosynthesis and transpiration. J. Expt. Bot. 49:387-398.

Kleinhenz, M.D., J.B. Bamberg, and J.P. Palta. 1995. Use of stomatal index as a marker to screen backcross populations of two wild potato species segregating for freezing tolerance. Amer. Potato J. 72:243-250.

Larkin, J.C., M.D. Marks, J. Nadeau, and F. Sack. 1997. Epidermal cell fate and patterning in leaves. Plant Cell 9:1109-1120.

Larsen, F.E. and J.F. Scholes. 1966. Effects of 8hydroxyquinoline citrate, $\mathrm{N}$-dimethyl amino succinamic acid, and sucrose on the vase-life and spike characteristics of cut snapdragon. Proc. Amer. Soc. Hort. Sci. 89:694-701

Lea, H.Z., G.M. Dunn, and D.W. Koch. 1977. Stomatal indexes in three ploidy levels of Bromus inermis Leyss. Crop Sci. 17:669-670.

Liang, G.H., A.D. Dayton, C.C. Chu, and A.J. Casady. 1975. Heritability of stomatal density and distribution on leaves of grain sorghum. Crop Sci. 15:567-570.

Littell, R.C., G.A. Milliken, W.W. Stroup, and R.D. Wolfinger. 1996. SAS system for mixed models. SAS Institute Inc., Cary, N.C.

Lugg, D.G. and T.R. Sinclair. 1979. Variation in stomatal density with leaf position in field-grown soybeans. Crop Sci. 19:407-409.

Marousky, F.J. 1969. Vascular blockage, water absorption, stomatal opening, and respiration of cut 'Better Times' roses treated with 8-hydroxyquinoline citrate and sucrose. J. Amer. Soc. Hort. Sci. 94:223-236.

Marousky, F.J. and J.C. Raulston. 1970. Interaction of flower preservative components and light on fresh weight and longevity of snapdragon flowers. Proc. Fla State Hort. Soc. 83:445-448.

Mayak, S., A.H. Halevy, S. Sagie, A. Bar-Yoseph, and B. Bravdo. 1974. The water balance of cut rose flowers. Physiol. Plant. 31:15-22.

Miskin, K.E. and D.C. Rasmusson. 1970. Frequency and distribution of stomata in barley. Crop Sci. 10:575-578.

Miskin, K.E., D.C. Rasmusson, and D.M. Moss. 1972. Inheritance and physiological effects of stomatal frequency in barley. Crop Sci. 12:780-783.

Mortensen, L.M. and T. Fjeld. 1998. Effects of air humidity, lighting period and lamp type on growth and vase life of roses. Scientia Hort. 73:229-237.

Mortensen, L.M. and H.R. Gislerød. 1999. Influence of air humidity and lighting period growth, vase life, and water relations of 14 rose cultivars. Scientia Hort. 82:289-298.

Nayeem, K.A. 1989. Genetical and environmental variation in stomatal frequency and distribution in wheat Triticum spp. Cereal Res. Comm.17:51-57.

Pappas, T., P. McManus, P. Vanderveer, and J. Croxdale. 1988. Characterization of stomatal development in Dianthus chinensis. Can. J. Bot. 66:142-149.

Paul, N.K. 1992. Variation in morpho-physiological characters in forage rape (Brassica napus L.) 2. Stomatal characters. Genet. Polonica 33:45-50.

Poehlman, J.M. and D.A. Sleper. 1995. Breeding field crops, p. 204. 4th ed. Iowa State Univ. Press, Ames.

Rawson, H.M. and C.L. Craven. 1975. Stomatal 
development during leaf expansion in tobacco and sunflower. Austral. J. Bot. 23:253-261.

Rogers, M.N. 1992. Snapdragons, p. 93-112.In:R.A. Larson (ed.). Introduction to floriculture, 2 nded. Academic Press, Inc. San Deigo, Calif.

Sampson, J. 1961. A method of replicating dry or moist surfaces for examination by light microscopy. Nature 191:932-933.

Schroeder, K.R. and D.P. Stimart. 1999. Postharvst life of Antirrhinum majus L. as influenced by number of stomata per cut flower stem. HortScience 34:501 (abstr.).

Slootweg, G. and U. van Meeteren. 1991. Transpiration and stomatal conductance of roses cv. Sonia grown with supplemental lighting. Acta Hort. 298:119-125.

Steel, R.G.D. and J.H. Torrie. 1980. Principles and procedures of statistics, a biometrical approach. 2nd ed. McGraw-Hill.
Stieve, S.M. and D.P. Stimart. 1994. Genetic analysis of postharvest longevity in Antirrhinum majus L. HortScience 29:435 (abstr.).

Tell, A.M. 1985. Frequency of stomates and their inheritance in Nicotiana. Egyptian J. Genet. Cytol. 14:171-177.

Tjia, B.O. and K.A. Funnell. 1986. Postharvest studies of cut Zantedeschia inflorescence. Acta Hort. 181:451-458.

van Doorn, W.G. 1997. Water relations in cut flowers. Hort. Rev. 18:1-85.

van Rensburg, L., J. Peacock and G.H.J. Krüger. 1999. Boundary layer, stomatal geometry and -spacing, in relation to drought tolerance of four Nicotiana tabacum L. cultivars. S. Afr. J. Plant Soil 16:44-49.

Walton, P.D. 1980. The production characteristics of Bromus inermis Leyss and their inheritance. In: Adv. Agron. 33:341-346.
Wild, A. and G. Wolf. 1980. The effect of different light intensities on the frequency and size of stomata, the size of cells, the number, size and chlorophyll content of chloroplasts in the mesophyll and the guard cells during the ontogeny of primary leaves of Sinapsis alba. Zeitschrift für Pflanzenphysiologie. 97:325-342.

Wilson, D. 1971. Selection responses of stomatal length and frequency, epidermal ridging, and other leaf characteristics in Lolium perenne L. 'Grasslands Ruanui'. N.Z. J. Agr. Res. 14:761-771.

Yamashita, H., H. Satoh, T. Omura, T. Takita, and H. Nishiyama. 1995. Difference in stomatal frequency in leaves of mutant lines and its inheritance in rice. Breeding Sci. 45:105-106.

Zhao, L. and F.D. Sack. 1999. Ultrastructure of stomatal development in Arabidopsis (Brassicaceae) leaves. Amer. J. Bot. 86:929-939. 